\title{
Mekanisme Persyaratan Teknik Perizinan Pemasukan Benih Tumbuhan dari Luar Negeri ke Sumatera Utara
}

\section{Mechanism Requirements For Engineering Licensing In Planting From Overseas To North Sumatera}

\author{
Roberty Melva Cristine Siagian*, Kartina Pakpahan** \& Fitra Fajar Akbar \\ Program Studi Ilmu Hukum, Fakultas Hukum, Universitas Prima Indonesia, Indonesia
}

Diterima: 14 Agustus 2020; Disetujui: 16 Agustus 2020; Dipublish: 17 Agustus 2020

*Coresponding Email: robertymelva1998@gmail.com, ** Email: kartinapakpahan@unprimdn.ac.id

\begin{abstract}
Provinsi Sumatera Utara membutuhkan penyediaan benih berkualitas untuk memenuhi permintaan kebutuhan tersebut dibutuhkan pemasukan (import). Tujuan penelitian menganalisis hukum positif, mekanisme persyaratan teknik, kendala perizinan pemasukan benih dari luar negeri di Sumut. Menggunakan metode penelitian yuridis empiris, dengan pendekatan kualitatif. Pemberlakuan atau implementasi ketentuan hukum normatif secara in action pada peristiwa hukum yang terjadi. Melakukan wawancara terhadap staf Balai Karantina Pertanian Kelas II Medan. Kesimpulan bahwa Pemasukan benih diatur khusus dalam UU No.21 Tahun 2019 Tentang Karantina Hewan, Ikan dan Tumbuhan. PP No.82 Tahun 2000, Peraturan Menteri Pertanian No. 15 Tahun 2017 tentang Pemasukan Dan Pengeluaran Benih Hortikultura dan Peraturan Menteri Pertanian No. 127 Tahun 2014 tentang Pemasukan dan Pengeluaran Benih Tanaman. Memperoleh izin dari Menteri Pertanian disertai sertifikat dari negara asal menyatakan benih bebas dari organisme pengganggu tumbuhan yaitu HpHK, HPIK, atau OPTK. Benih yang mengandung penyakit organisme pengganggu tumbuhan pada media tumbuhan diwilayah Sumatera Utara dapat diatasi Petugas dengan melakukan pengawasan secara intensif pada tempat pemasukan sebagai upaya perlindungan pencegahan membahayakan manusia termasuk merusak kelestarian sumber daya alam.
\end{abstract}

Abstrak

Kata Kunci: Persyaratan Teknik Perizinan, Pemasukan Benih Tumbuhan, Impor.

\begin{abstract}
North Sumatra Province requires the provision of quality seeds to meet the demand for import. The research objective is to analyze positive laws, technical requirements mechanisms, licensing constraints for importation of seeds from abroad in North Sumatra. Using empirical juridical research methods, with a qualitative approach. Enforcement or implementation of normative legal provisions in action on legal events that occur. Conducted interviews with the staff of the Class II Medan Agricultural Quarantine Center. The conclusion is that the import of seeds is specifically regulated in Law Number 21 of 2019 concerning Animal, Fish and Plant Quarantine. Government Regulation Number 82 of 2000, Regulation of the Minister of Agriculture Number 15 of 2017 concerning Importation and Exportation of Horticultural Seeds and Regulation of the Minister of Agriculture Number 127 of 2014 concerning Importation and Exportation of Plant Seeds. Obtaining a permit from the Minister of Agriculture accompanied by a certificate from the country of origin states that the seeds are free from plant-disturbing organisms, namely HpHK, HPIK, or OPTK. The officers can control the seeds that contain plant pests in plant media in North Sumatra by conducting intensive supervision at the entry point as an effort to protect against harm to humans, including damaging the preservation of natural resources.
\end{abstract}

Keywords: Licensing Technique Requirements, Import of Plant Seeds, Import.

How to Cite: Roberty Melva Cristine Siagian, Fitra Fajar Akbar \& Kartina Pakpahan (2020). Mekanisme Persyaratan Teknik Perizinan Pemasukan Benih Tumbuhan Dari Luar Negeri Ke Sumatera Utara. Journal of Education, Humaniora and Social Sciences (JEHSS): 241-252.

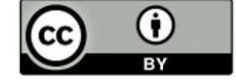


Vol 3, No. 1, Agustus 2020: 241 -251, DOI: https://doi.org/10.34007/jehss.v3i1.289

\section{PENDAHULUAN}

Kebutuhan benih dalam negeri masih belum dapat terpenuhi dengan baik (Rozi et al, 2014). Hal ini dikarenakan terbatasnya ketersediaan benih, baik dalam jumlah maupun kualitasnya (Sudjindro, 2016). Keragaman dalam kebutuhan benih yang tinggi dikalangan petani dan pelaku dalam usaha agribisnis, menggambarkan bahwa pada umumnya petani sudah menyadari pentingnya benih yang berkualitas. Sehubungan dengan pentingnya penyediaan benih yang berkualitas, memiliki kecenderungan untuk memenuhi permintaan dengan melalui impor benih (Litbang Pertanian, 2003), atau pemasukan benih ke provinsi Sumatera Utara.

Permintaan pemasukan benih impor dari luar negeri kedalam negeri khususnya wilayah Provinsi Sumatera Utara cukup beragam. Berdasarkan hasil pra-penelitian ternyata banyak pemasukan benih dari luar negeri ke dalam wilayah Indonesia selama lima tahun terakhir. Salah satunya pada tahun 2019 di wilayah Provinsi Sumatera Utara, menurut data yang diperoleh secara langsung dari Balai Karantina Pertanian Kelas II Medan pemasukan benih/bibit impor yaitu pemasukan 193.064 volume benih asal Papua Nugini dan Malaysia, 56.070 buah/butir/batang bibit krisan asal Vietnam, 1.500 buah/butir/batang benih karet asal Belgia, 11.750 volume benih bibit lilium asal Belanda dan Belgia, $138 \mathrm{~kg}$ benih lobak asal Jepang, dan 1500 buah/butir/batang bibit kurma asal Inggris telah mempunyai sertifikat dari negara asalnya (Wawancara, 2019).

Benih yang dimasukan ke dalam wilayah Sumatera Utara haruslah benih yang bermutu dan sesuai dengan standar mutu benih yang ada di Indonesia. Pada pasal 1 Peraturan Menteri Pertanian Republik Indonesia No. 15 Tahun 2017 tentang Pemasukan dan Pengeluaran Benih Hortikultura menjelaskan bahwasanya benih bermutu itu ialah benih yang telah didaftar untuk peredaran serta telah memenuhi standar (mutu) atau persyaratan teknis minimal yang ditetapkan dan peredarannya diawasi, yang benihnya berasal dari varietas Hortikultura. Standar mutu benih adalah spesifikasi teknis benih yang baku mencakup, mutu fisik, genetik, fisiologis, dan/atau kesehatan benih (Peraturan Menteri Pertanian Republik Indonesia No.15 Tahun 2017). Oleh karena itu identifikasi ada tidaknya penyakit terbawa benih yang disebabkan mikroorganisme sangat penting untuk diketahui status kesehatan benihnya (BBPPMBTPH, 2018). Benih yang disebut benih bermutu mencakup mutu genetis, adalah penampilan benih yang murni yang berasal dari suatu varietas tertentu yang merupakan identitas genetis dari tanaman induknya, mutu fisiologis adalah suatu kemampuan daya hidup benih yang mencakup daya/kekuatan tumbuh benih dan mutu fisik benih adalah penampilan benih secara sehat dilihat secara fisiknya yaitu ukuran homogen, bersih dari campuran, bebas hama/penyakit, serta kemasan yang menarik (BHP UMY, 2010).

Untuk memenuhi permintaan benih impor dengan tujuan penyediaan benih yang berkualitas di dalam negeri, maka dibutuhkan izin untuk pemasukan benih. Pemerintah pusat mengeluarkan kebijakan pengaturan izin pemasukan benih impor ke wilayah Indonesia, mengatur persyaratan teknis dan administrasi. Dalam mengimplementasikan peraturan tersebut didaerah dimungkinkan adanya kendala. Untuk mengetahui kendala yang dihadapi oleh Petugas di tempat Pemasukan Benih Impor. Hal tersebutlah yang melatar- belakangi penelitian ini dengan Judul "Analisis Yuridis Mekanisme Persyaratan Teknik Perizinan Pemasukan Benih dari Luar Negeri ke dalam Wilayah Provinsi Sumatera Utara".

\section{METODE PENELITIAN}

Metode penelitian yang dipergunakan sebagai cara utama untuk mencapai suatu tujuan. Penelitian ini mengunakan metode penelitian sebagai berikut:Hindari penulisan rumus-rumus statistik secara berlebihan.

Penelitian ini menggunakan pendekatan kualitatif, jenis penelitian normatif empiris. Pendekatan kualitatif dapat digunakan apabila ingin melihat dan mengungkapkan suatu keadaan maupun suatu objek dalam konteksnya, menemukan makna (meaning) atau pemahaman yang mendalam tentang suatu masalah yang dihadapi, yang tampak dalam bentuk data kualitatif, baik

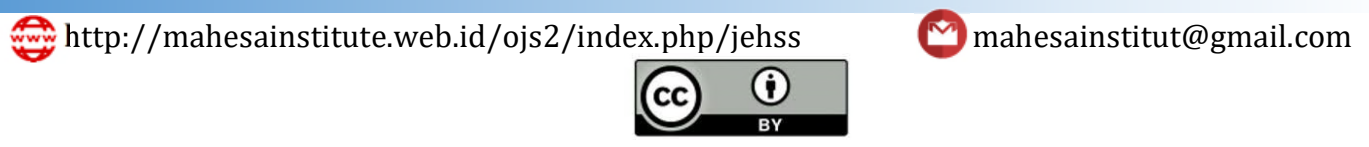


berupa gambar, kata, maupun kejadian serta dalam "natural setting" (Yusuf, 2017). Metode penelitian hukum normatif yang meneliti hukum dari perspektif internal dengan objek penelitiannya adalah norma hukum (Diantha, 2017). Metode penelitian hukum normatif yang meneliti hukum dari perspektif internal dengan objek penelitiannya adalah norma hukum. Penelitian hukum tentang pemberlakuan ketentuan hukum normatif (undang-undang, secara in action pada setiap peristiwa hukum tertentu yang terjadi dalam masyarakat) (Muhammad, 2004) yang berkaitan dengan penelitian. Penelitian hukum normatif berdasarkan bahan baku utama, menelaah hal yang bersifat teoritis (peraturan) menggunakan data sekunder yaitu aturan hukum (peraturan perundang - undangan, buku - buku, dokumen berhubungan erat dengan penelitian) (Soekanto, 2006). Penelitian hukum empiris yaitu penelitian secara langsung (ke lapangan) untuk melihat penerapan dari aturan hukum (perundang - undangan) yang berkaitan dengan penegakan hukum, dan melakukan wawancara dengan staf Balai Karantina Pertanian Kelas II Medan.

Metode Pengumpulan Data: Pengumpulan data dilakukan melalui studi kepustakaan dan lapangan; Penelitian hukum normatif dalam penelitian ini adalah studi pustaka, yaitu mempelajari bahan (data sekunder), dengan menggali norma, kaidah dari peraturan perundang-undangan; Penelitian hukum empiris atau sosiologis, adalah hukum meninjau atau menilik dirinya dari unsur - unsur diluar dirinya (hukum), yaitu fenomena - fenomena sosial di dunia kenyataan (empiris) yang mempengaruhi perilaku hukum baik secara personal individual, maupun secara institusional masyarakat dan lembaga - lembaga hukum yang eksis (Qamar, 2017).

Jika analisis empiris dibutuhkan dalam penelitian normatif, maka pendekatan dari segi empiris dapat membantu terhadap penelitian normatif, namun dengan konsekuensi penggunaan metode yang berbeda dengan pemisahan yang jelas dan tegas (Jonaedi \& Johnny, 2014).

Teknik Analisa Data dilakukan dengan cara diambil dari bahan hukum primer, bahan hukum sekunder, dan bahan hukum tersier yang sudah dikumpulkan dan dianalisis (secara deskriptif) dengan logika deduktif. Untuk mendapatkan penjelasan yang sistematis bahan hukum tersebut akan diuraikan. Dilakukan pendeskripsian untuk menentukan isi (makna bahan hukum) yang sesuai dengan pokok permasalahn. Dari data yang sudah terkumpul kemudian dilakukan analisis deskriptif kualitatif yaitu analisis yang menunjukkan keadaan sebenarnya mengenai fakta-fakta tertentu.

\section{HASIL DAN PEMBAHASAN}

Peraturan Hukum Positif Yang Berkaitan Dengan Mekanisme Persyaratan Teknik Perizinan Pemasukan Benih Dari Luar Negeri.

Berdasarkan Undang - Undang No. 12 Tahun 2011 Tentang Pembentukan Peraturan Perundang-undangan Republik Indonesia. Sebagai dasar pembentukan peraturan perundangundangan yang berlaku di Indonesia. Peraturan hukum positif yang berkaitan dengan mekanisme persyaratan teknik perizinan pemasukan benih dari luar negeri ke dalam wilayah Sumatera Utara terdiri dari: 
Tabel 1. Mekanisme Persyaratan Teknik Perizinan Pemasukan Benih Dari Luar Negeri Ke Dalam Wilayah Negara Indonesia Diatur Dalam Undang - Undang.

\begin{tabular}{|c|c|}
\hline No. & Undang - Undang. \\
\hline 1. & $\begin{array}{l}\text { Undang - Undang No. } 21 \text { Tahun } 2019 \text { tentang Karantina Hewan, Ikan, } \\
\text { dan Tumbuhan. }\end{array}$ \\
\hline 2. & $\begin{array}{l}\text { Undang - Undang No. } 19 \text { Tahun } 2016 \text { tentang Informasi dan Transaksi } \\
\text { Elektronik. }\end{array}$ \\
\hline 3. & Undang - Undang No. 17 Tahun 2006 tentang Kepabeaan. \\
\hline 4. & Undang - Undang No. 01 Tahun 2009 tentang Penerb \\
\hline 5. & $\begin{array}{l}\text { Undang - Undang No. } 05 \text { Tahun } 1990 \text { tentang Konserv } \\
\text { Alam. }\end{array}$ \\
\hline 6. & Undang - Undang No. 08 Tahun 1999 tentang Perlindu \\
\hline 7. & Undang - Undang No. 17 Tahun 2008 ten \\
\hline 8. & Undang - Undang No. 25 Tahun 2009 ter \\
\hline 9. & Undang - Undang No. 13 Tahun 2010 tentang Hortikultı \\
\hline 10. & $\begin{array}{l}\text { Undang - Undang No. } 19 \text { Tahun } 2009 \text { tentang Konvensi Stockholm } \\
\text { Tentang Bahan Pencemar Organik Yang Persisten. }\end{array}$ \\
\hline 11. & Undang - Undang No. 24 Tahun 2000 tenta \\
\hline 12. & $\begin{array}{l}\text { Undang - Undang No. } 29 \text { Tahun } 2000 \text { tentang Perlindungan Varietas } \\
\text { Tanaman. }\end{array}$ \\
\hline 13. & Undang - Undang No. 19 Tahun 2004 tentang Kehuta \\
\hline 14. & - Undang No. 38 Tahı \\
\hline 15. & $\begin{array}{l}\text { Undang - Undang No. } 22 \text { Tahun } 2019 \text { tentang Sistem Budidaya } \\
\text { Pertanian Berkelanjutan. }\end{array}$ \\
\hline 16. & Undang - Undang No. 07 Tahun 2014 tentang Perdagangan. \\
\hline 17. & $\begin{array}{l}\text { Undang - Undang No. 04 Tahun } 2006 \text { tentang Pengesahan International } \\
\text { Treaty On Plan Genetic Resources For Food And Agriculture (Perjanjian } \\
\text { Mengenai Sumber Daya Genetik Tanaman Untuk Pangan Dan }\end{array}$ \\
\hline
\end{tabular}

Tabel 2. Mekanisme Persyaratan Teknik Perizinan Pemasukan Benih Dari Luar Negeri Ke Dalam Wilayah Negara Indonesia Diatur Dalam Peraturan Pemerintah.

\begin{tabular}{|c|l|}
\hline No. & Peraturan Pemerintah. \\
\hline 1. & $\begin{array}{l}\text { Peraturan Pemerintah No. 08 Tahun } 1999 \text { tentang Pemanfaatan Jenis } \\
\text { Tumbuhan Dan Satwa Liar. }\end{array}$ \\
\hline 2. & Peraturan Pemerintah No. 14 Tahun 2002 tentang Karantina Tumbuhan. \\
\hline 3. & $\begin{array}{l}\text { Peraturan Pemerintah No. } 18 \text { Tahun } 2010 \text { tentang Usaha Budidaya } \\
\text { Tanaman. }\end{array}$ \\
\hline 4. & $\begin{array}{l}\text { Peraturan Pemerintah No. } 21 \text { Tahun } 2005 \text { tentang Keamanan Hayati } \\
\text { Produk Rekayasa Genetika. }\end{array}$ \\
\hline 5. & $\begin{array}{l}\text { Peraturan Pemerintah No. 35 Tahun } 2016 \text { tentang Jenis Dan Tarif Jasa } \\
\text { Kementras Jenis Penerimaan Barang Bukan Pajak Yang Berlaku Pada } \\
\text { Kementanian. }\end{array}$ \\
\hline 7. & $\begin{array}{l}\text { Peraturan Pemerintah No. 96 Tahun 2012 tentang Pelaksanaan Undang } \\
\text { Peraturan Pemerintah No. 44 Tahun 1995 tentang Pembenihan } \\
\text { Tanaman. }\end{array}$ \\
\hline
\end{tabular}

Tabel 3. Mekanisme Persyaratan Teknik Perizinan Pemasukan Benih Dari Luar Negeri Ke Dalam Wilayah Negara Indonesia Diatur Dalam Peraturan Presiden.

\begin{tabular}{|c|l|}
\hline No. & Peraturan Presiden. \\
\hline 1. & $\begin{array}{l}\text { Peraturan Presiden Republik Indonesia No. } 44 \text { Tahun } 2018 \text { tentang } \\
\text { Indonesian National Single Window. }\end{array}$ \\
\hline 2. & $\begin{array}{l}\text { Peraturan Presiden Republik Indonesia No. } 53 \text { Tahun } 2014 \text { tentang } \\
\text { Perubahan Atas Peraturan Presiden No. 39 Tahun } 2010 \text { tentang Komisi } \\
\text { Keamanan Hayati Produk Rekayasa Genetika. }\end{array}$ \\
\hline
\end{tabular}

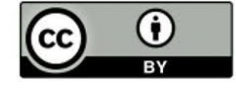


Vol 3, No. 1, Agustus 2020: 241 -251, DOI: https://doi.org/10.34007/jehss.v3i1.289

Tabel 4. Mekanisme Persyaratan Teknik Perizinan Pemasukan Benih Dari Luar Negeri Ke Dalam Wilayah Negara Indonesia Diatur Dalam Peraturan Menteri.

\begin{tabular}{|c|c|}
\hline No. & Peraturan Menteri. \\
\hline 1. & $\begin{array}{l}\text { Permentan No. } 42 \text { Tahun } 2014 \text { tentang Tindakan Karantina Tumbuhan } \\
\text { Untuk Pemaskan Buah Segar Dan Sayur Segar Kedalam Wilayah } \\
\text { Negara Kesatuan Republik Indonesia. }\end{array}$ \\
\hline 2. & $\begin{array}{l}\text { Permentan No. } 43 \text { Tahun } 2014 \text { tentang Tindakan Karantina Tumbuhan } \\
\text { Untuk Pemaskan Umbi Lapis Segar Kedalam Wilayah Negara Kesatuan } \\
\text { Republik Indonesia. }\end{array}$ \\
\hline 3. & $\begin{array}{l}\text { Permentan No. } 51 \text { Tahun } 2015 \text { tentang Penggolongan Jenis Organisme } \\
\text { Pengganggu Tumbuhan Karantina. }\end{array}$ \\
\hline 4. & $\begin{array}{l}\text { Permentan No. } 12 \text { Tahun } 2009 \text { tentang Persyaratan Dan Tata Cara } \\
\text { Tindakan Karantina Tumbuhan Terhadap Pemasukan Kemasan Kayu } \\
\text { Kedalam Wilayah Negara Republik Indonesia. }\end{array}$ \\
\hline 5. & $\begin{array}{l}\text { Permentan No. } 15 \text { Tahun } 2017 \text { tentang Pemasukan Dan Pengeluaran } \\
\text { Benih Hortikultura. }\end{array}$ \\
\hline 6. & $\begin{array}{l}\begin{array}{l}\text { Permentan No. } 52 \\
\text { Karantina Tumbuhan. }\end{array} \text { Tahun } 2006 \text { tentang Persyaratan Tambahan } \\
\end{array}$ \\
\hline 7. & $\begin{array}{l}\text { Permentan No. } 271 \text { Tahun } 2006 \text { tentang Persyaratan Dan Tata Cara } \\
\text { Pelaksanaan Tindakan Karantina Tertentu Oleh Pihak Ketiga. }\end{array}$ \\
\hline 8. & $\begin{array}{l}\text { an No. } 55 \text { Tahun } 2016 \text { tentang Pengawasan Keamanan Pangan } \\
\text { pemasukan Pangan Segar Asal Tumbuhan. }\end{array}$ \\
\hline 9. & $\begin{array}{l}\text { an No. } 73 \text { Tahun } 2012 \text { tentang Tata Cara Penetapan Instalasi } \\
\text { Tumbuhan Milik Perorangan Atau Badan Hukum. }\end{array}$ \\
\hline 10. & $\begin{array}{l}\text { Permentan No. } 68 \text { Tahun } 2007 \text { tentang Perubahan Atas Permentan No. } \\
38 \text { Tahun } 2006 \text { tentang Pemasukan Dan Pengeluaran Benih Serta } \\
\text { Lampiran. }\end{array}$ \\
\hline 11. & $\begin{array}{l}\text { ntan No. } 67 \text { Tahun } 2006 \text { tentang Pelestarian Dan Pemanfaatan } \\
\text { r Daya Genetik Tanaman. }\end{array}$ \\
\hline 12. & $\begin{array}{l}\begin{array}{l}\text { Permentan No. } 60 \\
\text { Hortikultura. }\end{array}\end{array}$ \\
\hline 13. & $\begin{array}{l}\text { tan No. } 57 \text { Tahun } 2015 \text { tentang Pemasukan Dan Pengeluaran } \\
\text { Pakan Asal Tumbuhan Ke Dan Dari Wilayah Republik Indonesia. }\end{array}$ \\
\hline 14. & $\begin{array}{l}\text { Permenkeu No. } 105 \text { Tahun } 2007 \text { tentang Pembebasan Bea Masuk Atas } \\
\text { Impor Bibit Dan Benih Untuk Pembangunan Industri Pertanian, } \\
\text { Peternakan Atau Perikanan. }\end{array}$ \\
\hline 15. & $\begin{array}{l}\text { tan No. } 31 \text { Tahun } 2015 \text { tentang Perubahan Atas Permentan No. } \\
\text { un } 2011 \text { tentang Organisme Pengganggu Tumbuhan Karantina. }\end{array}$ \\
\hline 16. & $\begin{array}{l}\text { tan No. } 50 \text { Tahun } 2015 \text { tentang Produksi, Sertifikasi, Peredaran } \\
\text { ngawasan Benih Tanaman Perkebunan. }\end{array}$ \\
\hline 17. & $\begin{array}{llccccc}\text { Permentan No. } 35 & \text { Tahun } 2017 \text { tentang Perubahan Kedua Atas } \\
\text { Permentan No. } 94 \text { Tahun } 2011 \text { tentang Tentang Pemasukan Dan } \\
\text { Pengeluaran Media Pembawa Penyakit Hewan Karantina Dan } \\
\text { Organismeb Penggangu Tumbuhan Karantina. }\end{array}$ \\
\hline 18. & $\begin{array}{l}\text { entan No. } 117 \text { Tahun } 2013 \text { tentang Pelayanan Perizinan Pertanian } \\
\text { a Online (Berita Negara Republik Indonesia Tahun } 2013 \text { No. 1323). }\end{array}$ \\
\hline 19. & $\begin{array}{l}\text { Permentan No. } 37 \text { Tahun } 2009 \text { tentang Pestisida Berbahan Metil } \\
\text { Bromida Untuk Tindakan Perlakuan Tindakan Karantina Tumbuhan Dan } \\
\text { Perlakuan Pra Pengapalan. }\end{array}$ \\
\hline 20. & $\begin{array}{l}\text { Permentan No. } 20 \text { Tahun } 2017 \text { tentang Perubahan Atas Permentan No. } \\
12 \text { Tahun } 2015 \text { tentang Tindakan Karantina Tumbuhan Untuk } \\
\text { Pemasukan Sayuran Umbi Lapis Segar Ke Dalam Republik Indonesia. }\end{array}$ \\
\hline 23. & $\begin{array}{l}\text { Permenkeu No. } 01 \text { Tahun } 2017 \text { tentang Tindakan Karantina Tumbuhan } \\
\text { Pengeluaran Media Pembawa Organisme Pengganggu Tumbuhan } \\
\text { Karantina Di Tempat Pemeriksaan Karantina. }\end{array}$ \\
\hline 24 & $\begin{array}{l}\text { Peraturan Menteri Pendayagunaan Aparatur Negara Dan Reformasi } \\
\text { Birokrasi Republik Indonesia No. } 16 \text { Tahun } 2018 \text { tentang Jabatan } \\
\text { Fungsional Pemeriksa Tumbuhan. }\end{array}$ \\
\hline 25. & $\begin{array}{l}\text { Peraturan Menteri Pendayagunaan Aparatur Negara Dan Reformasi } \\
\text { Birokrasi Republik Indonesia No. } 15 \text { Tahun } 2018 \text { tentang Fungsional }\end{array}$ \\
\hline
\end{tabular}

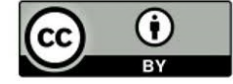

This work is licensed under a Creative Commons Attribution 4. 
Tabel 5. Mekanisme Persyaratan Teknik Perizinan Pemasukan Benih Dari Luar Negeri Ke Dalam Wilayah Negara Indonesia Diatur Dalam Keputusan Menteri.

\begin{tabular}{|c|c|}
\hline No. & eri. \\
\hline 1. & $\begin{array}{l}\text { Keputusan Menteri Pertanian No. } 100 \text { Tahun } 2016 \text { tentang Registrasi } \\
\text { Laboratorium Penguji Keamanan Pangan Segar Asal Tumbuhan Negara } \\
\text { Korea Selatan. }\end{array}$ \\
\hline 2. & $\begin{array}{l}\text { Keputusan Menteri Pertanian No. } 103 \text { Tahun } 2016 \text { tentang Registrasi } \\
\text { Laboratorium Penguji Keamanan Pangan Segar Asal Tumbuhan Negara } \\
\text { Thailand. }\end{array}$ \\
\hline 3. & $\begin{array}{l}\text { Keputusan Menteri Pertanian No. } 227 \text { Tahun } 2016 \text { tentang Registrasi } \\
\text { Laboratorium Penguji Keamanan Pangan Segar Asal Tumbuhan Negara } \\
\text { Vietnam. }\end{array}$ \\
\hline 4. & $\begin{array}{l}\text { Keputusan Menteri Pertanian No. } 234 \text { Tahun } 2016 \text { tentang Registrasi } \\
\text { Laboratorium Penguji Keamanan Pangan Segar Asal Tumbuhan Negara } \\
\text { Afrika Selatan. }\end{array}$ \\
\hline 5. & $\begin{array}{l}\text { Keputusan Menteri Pertanian No. } 4484 \text { Tahun } 2013 \text { tentang Pengakuan } \\
\text { Terhadap Sitem Pengawasan Keamanan Pangan Segar Asal Tumbuhan } \\
\text { Negara Kanada. }\end{array}$ \\
\hline 6. & $\begin{array}{l}\text { Keputusan Menteri Pertanian No. } 1821 \text { Tahun } 2013 \text { tentang Pengakuan } \\
\text { Terhadap Sitem Pengawasan Keamanan Pangan Segar Asal Tumbuhan } \\
\text { Negara Italia. }\end{array}$ \\
\hline 7. & $\begin{array}{l}\text { Keputusan Menteri Pertanian No. } 1820 \text { Tahun } 2016 \text { tentang Registrasi } \\
\text { Laboratorium Penguji Keamanan Pangan Segar Asal Tumbuhan Negara } \\
\text { Sri Langka. }\end{array}$ \\
\hline 8. & $\begin{array}{l}\text { Keputusan Menteri Pertanian No. } 1597 \text { Tahun } 2016 \text { tentang Registrasi } \\
\text { Laboratorium Penguji Keamanan Pangan Segar Asal Tumbuhan Wilayah } \\
\text { Kepabeaan Taiwan, Penghu, Kinmen Dan Matsu. (The Separaty Costum } \\
\text { Territory Of Taiwan, Penghu, Kinmen And Matsu). }\end{array}$ \\
\hline 9. & $\begin{array}{l}\text { Keputusan Menteri Pertanian No. } 1596 \text { Tahun } 2016 \text { tentang Registrasi } \\
\text { Laboratorium Penguji Keamanan Pangan Segar Asal Tumbuhan Negara } \\
\text { Brazil. }\end{array}$ \\
\hline 10. & $\begin{array}{l}\text { Keputusan Menteri Pertanian No. } 1595 \text { Tahun } 2016 \text { tentang Registrasi } \\
\text { Laboratorium Penguji Keamanan Pangan Segar Asal Tumbuhan Negara } \\
\text { Jerman. }\end{array}$ \\
\hline 11. & $\begin{array}{l}\text { Keputusan Menteri Pertanian No. } 1178 \text { Tahun } 2016 \text { tentang Registrasi } \\
\text { Laboratorium Penguji Keamanan Pangan Segar Asal Tumbuhan Negara } \\
\text { Federasi Rusia. }\end{array}$ \\
\hline 12. & $\begin{array}{l}\text { Keputusan Menteri Pertanian No. } 977 \text { Tahun } 2016 \text { tentang Registrasi } \\
\text { Laboratorium Penguji Keamanan Pangan Segar Asal Tumbuhan Negara } \\
\text { Mesir. }\end{array}$ \\
\hline 13. & $\begin{array}{l}\text { Keputusan Menteri Pertanian No. } 968 \text { Tahun } 2016 \text { tentang Registrasi } \\
\text { Laboratorium Penguji Keamanan Pangan Segar Asal Tumbuhan Negara } \\
\text { Jepang. }\end{array}$ \\
\hline 14. & $\begin{array}{l}\text { Keputusan Menteri Pertanian No. } 967 \text { Tahun } 2016 \text { tentang Registrasi } \\
\text { Laboratorium Penguji Keamanan Pangan Segar Asal Tumbuhan Negara } \\
\text { Chili. }\end{array}$ \\
\hline 15. & $\begin{array}{l}\text { Keputusan Menteri Pertanian No. } 881 \text { Tahun } 2016 \text { tentang Registrasi } \\
\text { Laboratorium Penguji Keamanan Pangan Segar Asal Tumbuhan Negara } \\
\text { China. }\end{array}$ \\
\hline 16. & $\begin{array}{l}\text { Keputusan Menteri Pertanian No. } 883 \text { Tahun } 2016 \text { tentang Registrasi } \\
\text { Laboratorium Penguji Keamanan Pangan Segar Asal Tumbuhan Negara } \\
\text { Uni Emirat Arab. }\end{array}$ \\
\hline 17. & $\begin{array}{l}\text { Keputusan Menteri Pertanian No. } 778 \text { Tahun } 2016 \text { tentang Registrasi } \\
\text { Laboratorium Penguji Keamanan Pangan Segar Asal Tumbuhan Negara } \\
\text { Prancis. }\end{array}$ \\
\hline 18. & $\begin{array}{l}\text { Keputusan Menteri Pertanian No. } 723 \text { Tahun } 2016 \text { tentang Registrasi } \\
\text { Laboratorium Penguji Keamanan Pangan Segar Asal Tumbuhan Negara } \\
\text { Austria. }\end{array}$ \\
\hline 19. & $\begin{array}{l}\text { Keputusan Menteri Pertanian No. } 722 \text { Tahun } 2016 \text { tentang Registrasi } \\
\text { Laboratorium Penguji Keamanan Pangan Segar Asal Tumbuhan Negara } \\
\text { Spanyol. }\end{array}$ \\
\hline
\end{tabular}

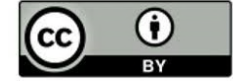


Vol 3, No. 1, Agustus 2020: 241 -251, DOI: https://doi.org/10.34007/jehss.v3i1.289

Tabel 6. Mekanisme Persyaratan Teknik Perizinan Pemasukan Benih Dari Luar Negeri Ke Dalam Wilayah Negara Indonesia Diatur Dalam Keputusan Kepala Badan.

\begin{tabular}{|c|c|}
\hline & \\
\hline 1. & $\begin{array}{l}\text { eputusan Kepala Badan Pertanian No. } 798 \text { Tahun } 2014 \text { tentang } \\
\text { edoman Registrasi Perusahaan Fumigasi Metil Bromida Skim Audit } \\
\text { adan Karantina Pertanian. }\end{array}$ \\
\hline 2. & $\begin{array}{l}\text { Keputusan Kepala Badan Pertanian No. } 699 \text { Tahun } 2010 \text { tentang } \\
\text { Pedoman Registrasi Perusahaan Kemasan Kayu Skim Audit Badan } \\
\text { Karantina Pertanian. }\end{array}$ \\
\hline 3. & $\begin{array}{l}\text { epala Badan Pertanian No. } 1645 \text { Tahun } 2013 \text { tentang } \\
\text { gistrasi Perusahaan Fumigasi Metil Bromida Skim Audit } \\
\text { ina Pertanian. }\end{array}$ \\
\hline 4. & $\begin{array}{l}\text { la Badan Pertanian No. } 1644 \text { Tahun } 2013 \text { tentang } \\
\text { asi Perusahaan Fumigasi Metil Bromida Skim Audit } \\
\text { Pertanian. }\end{array}$ \\
\hline 5. & $\begin{array}{l}\text { ala Badan Pertanian No. } 855 \text { Tahun } 2015 \text { tentang } \\
\text { rasi Perusahaan Fumigasi Metil Bromida Skim Audit } \\
\text { Pertanian. }\end{array}$ \\
\hline 6. & $\begin{array}{l}\text { la Badan Pertanian No. } 698 \text { Tahun } 2010 \text { tentang } \\
\text { asi Perusahaan Fumigasi Metil Bromida Skim Audit } \\
\text { Pertanian. }\end{array}$ \\
\hline 7. & $\begin{array}{l}\text { Jan Pertanian No. } 605 \text { Tahun } 2012 \text { tentang } \\
\text { rusahaan Fumigasi Metil Bromida Skim Audit } \\
\text { an. }\end{array}$ \\
\hline 8. & $\begin{array}{l}\text { an Pertanian No. } 442 \text { Tahun } 2015 \\
\text { usahaan Fumigasi Metil Bromida Ski }\end{array}$ \\
\hline
\end{tabular}

Menurut Permentan No. 15 Tahun 2017 izin pemasukan merupakan keterangan tertulis yang berisikan hak yang diberikan oleh Menteri (pejabat yang ditunjuk kepada badan usaha, badan hukum, instansi pemerintah, Pemerhati Tanaman, dan Pelanggan Luar Negeri) untuk dapat melaksanakan kegiatan pemasukan benih dari luar negeri. Pemasukan benih harus disertai Surat Izin Pemasukan dari Menteri Pertanian (SIP Mentan) dan sesuai dengan Permentan No. 127 Tahun 2014 tentang Pemasukan dan Pengeluaran Benih Tanaman. Pemasukan benih dapat dilakukan setelah memperoleh izin dari Menteri. Pemberian izin pemasukan benih sebagaimana diatur dalam Pasal 5 Permentan (Peraturan Menteri Pertanian) No. 15 Tahun 2017 dilakukan oleh Menteri yang dimandatkan atas Direktur Jendral atas nama Menteri

\section{Tata Cara Permohononan Perizinan Pemasukan Benih Dari Luar Negeri Ke wilayah Sumatera Utara.}

Perizinan mempunyai fungsi sebagai pengendalian dari aktivitas - aktivitas pemerintah terkait ketentuan-ketentuan yang berisi pedoman yang harus dilaksanakan baik oleh yang berkepentingan ataupun oleh pejabat yang diberi kewenangan (Mohammad Refsanjani Arman Al Halim, 2017). Begitupula dengan aktivitas pemasukan benih yang berasal dari luar negeri untuk masuk ke wilayah Indonesia khususnya Sumatera Utara pun memiliki izin yang harus dipenuhi.

Tata Cara Pemasukan Benih Impor dari Luar Negeri Ke Sumut, sebagai berikut:

1. Persyaratan Pemasukan Tanaman Benih Hortikultura:

a. Persyaratan administrasi diatur dalam Pasal 10 Permentan No. 15 Tahun 2017 tentang Pemasukan Dan Pengeluaran Benih Hortikultura.

b. Persyaratan teknis diatur dalam Pasal 24 Permentan No. 15 Tahun 2017 tentang Pemasukan Dan Pengeluaran Benih Hortikultura.

2. Persyaratan Pemasukan Tanaman Benih Tanaman Pangan/Pekebunan:

a. Persyaratan administrasi diatur dalam Pasal 7 Permentan No. 127 Tahun 2014 tentang Pemasukan dan Pengeluaran Benih Tanaman.

b. Persyaratan teknis diatur dalam Pasal 21 Permentan No. 127 Tahun 2014 tentang Pemasukan dan Pengeluaran Benih Tanaman. 


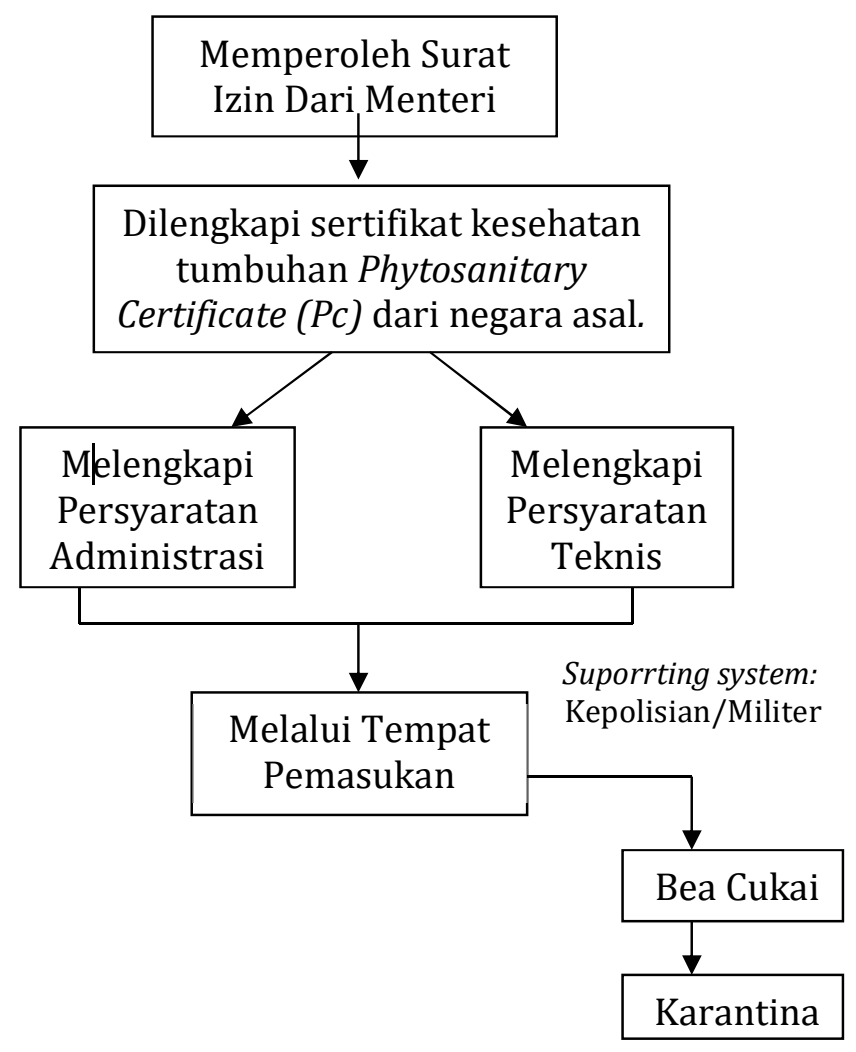

\section{Bagan 1. Tata Cara Pemasukan Benih Impor}

\section{Note:}

Melalui tempat pemasukan:

Pelabuhan Laut Belawan, Medan;

Bandara Udara Kualanamu, Deliserdang;

Pelabuhan Teluk Nibung, Tanjungbalai, Asahan.

Pemasukan benih ke dalam wilayah Sumatera Utara dilaksanakan oleh beberapa institusi yang berwenang. Dengan kerja sama dan pembagian informasi di antara institusi-institusi yang terlibat bersumber dari website Dewan Perwakilan Rakyat Republik Indonesia, yaitu:

1. Bea Cukai (Customs), dalam pemasukan benih Bea cukai berfungsi mencakup pungutan bea dan pungutan cukai. Akan tetapi pemasukan benih impor dari luar negeri ke dalam wilayah Republik Indonesia diberikan pembebasan bea masuk dan harus mengajukan permohonan pembebasan bea masuk kepada Menteri melalui Direktur Jenderal, yang terdapat pada Pasal 2, Pasal 3, dan Pasal 4 Permenkeu (Peraturan Menteri Keuangan) No. 105 Tahun 2007 tentang pembebasan Bea Masuk Atas Impor Bibit dan Benih Untuk Pembangunan dan Pengembangan Industri Pertanian, Peternakan, atau Perikanan.

2. Karantina (Quarantine), karantina merupakan tindakan pencegahan dan penangkalan masuk dan tersebarnya organisme pengganggu (hama penyakit) tumbuhan yaitu media pembawa, HPTK, dan OPTK ke dalam wilayah Indonesia berdasarkan standar dan peraturan perundangan yang berlaku ke dalam wilayah Sumatera Utara.

3. Selain institusi-institusi di atas, kepolisian dan/atau militer berfungsi sebagai supporting system pada keadaan normal. Adapun otoritas pelabuhan dan bandara udara menjadi otoritas yang mengkoordinir institusi - institusi tersebut sehingga semua institusi yang berwenang dapat melaksanakan fungsinya dengan baik. Pada dasarnya dua otoritas diatas merupakan unsur dari pemerintah yang melaksanakan fungsi pengaturan, pengendalian, dan pengawasan

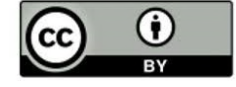


terhadap kegiatan kepelabuhanan atau kebandarudaraan yang diusahakan secara komersial menurut peraturan perundang-undangan di bidang kepelabuhanan atau kebandarudaraan.

\section{Pemasukan Benih Impor Tanpa Izin}

Dalam ketentuan hukum di Indonesia pelanggaran pemasukan benih impor tanpa izin diatur pada Pasal 108 ayat (1) huruf a dan ayat (2) UU (Undang - Undang) No 22 Tahun 2019 tentang Sistem Budi Daya Pertanian Berkelanjutan. Sanksi administratif ayat (1) dapat berupa: sebagaimana dimaksud pada teguran tertulis, denda administratif, penghentian sernentara kegiatan usaha, penarikan produk dari peredaran, pencabutan izin, dan/atau penutupan usaha."

1. Adapun pasal 44 ayat (2) dan ayat (3) yaitu: Pemasukan sebagaimana dimaksud pada ayat (1) wajib memenuhi standar mutu. Setiap Orang yang melakukan pemasukan sebagaimana dimaksud pada ayat (1) wajib memperoleh izin dari Menteri.

2. Adapun unsur - unsur pasal tersebut yaitu:

a. Standar mutu, standar mutunya ditetapkan tersendiri oleh Pemerintah menurut Pasal 17 ayat (3) Penjelasan Atas Undang-Undang Republik Indonesia Nomor 12 Tahun 1992 Tentang Sistem Budidaya Tanaman.

b. Setiap orang, mengenai "setiap orang" mempunyai arti bahwa merupakan subjek atau pelaku delik, bahwa yang menjadi pelaku delik adalah manusia atau orang perorangan.

c. Memperoleh izin Menteri, mengenai "memperoleh izin" mempunyai arti bahwa mendapatkan Izin: vergunning ialah suatu penetapan yang merupakan dispensasi dari pada suatu larangan oleh undang-undang (Muladi \& Dwidja, 2010) dari Menteri.

\section{Analisis Kasus}

Kepala Kantor Bea Cukai Teluk Nibung I Wayan Sapta Dharma melakukan penindakan pada Selasa 17 September 2019 terhadap barang importasi bawaan salah satu penumpang dari negara Malaysia di terminal pelabuhan Teluk Nibung. Yang pada saat diperiksa dengan menggunakan mesin x-ray terdapat barang yaitu, 60 (enam puluh) buah bibit kaktus, 10 (sepuluh) buah bibit kelapa dan 32 (tiga puluh dua) Kg apel yang dicurigai tidak memenuhi ketentuan lartas dan tidak dilengkapi dokumen sesuai dengan ketentuan pada Pasal 2 jo Pasal 5 Peraturan Pemerintah No. 14 Tahun 2002 Tentang Karantina Tumbuhan. Untuk pemeriksaan lebih lanjut, Bea Cukai menyerahkan barang hasil penindakan tersebut kepada Balai Karantina Pertanian Tanjungbalai Asahan (Direktorat Jendral Bea Dan Cukai, 2019).

Berdasarkan perbuatan yang dilakukan oleh penumpang dari negara Malaysia tersebut telah memenuhi unsur Pasal 108 ayat (1) dan ayat (2) UU (Undang - Undang) No. 22 Tahun 2019 tentang Sistem Budi Daya Pertanian Berkelanjutan yang mana:

1. Setiap orang, bahwa merupakan subjek atau pelaku delik (orang), yaitu seorang penumpang dari negara Malaysia

2. Melanggar Ketentuan, penumpang dari negara Malaysia menyalahi aturan atau melawan aturan yaitu benih yang dibawa masuk ke Indonesia lewat Teluk Nibung tidak dilengkapi dokumen yang sesuai ketentuan yang berlaku berdasarkan pada Pasal 2 jo Pasal 5 Peraturan Pemerintah No. 14 Tahun 2002 Tentang Karantina Tumbuhan. Setelah terpenuhinya unsur pada pasal 108 ayat (1) maka menurut pasal 108 ayat (2) si subjek yang merupakan penumpang dari negara Malaysia akan dikenakan sanksi sesuai pasal yang mengatur, berupa: 1) Jika subjek merupakan orang perseorangan: a) Teguran tertulis; b) Denda administratif.

2) Jika subjek merupakan Badan Usaha: a) Penghentian sernentara kegiatan usaha; b) Penarikan produk dari peredaran; c) Pencabutan izin; d) \Penutupan usaha.

Sanksi tegas pun diberikan oleh pihak Balai Karantina Pertanian Tanjungbalai Asahan yaitu pemusnahan terhadap benih benih yang tidak memiliki sertifikat yang menyatakan bahwa benih yang masuk aman bebas dari penyakit Organisme Pengganggu Tumbuhan Karantina (OPTK) dan dilampirkan dengan sertifikat yang berasal dari lembaga yang resmi yang dimana terlebih dahulu di karantina di negara asal serta tidak memiliki surat izin dari Menteri.

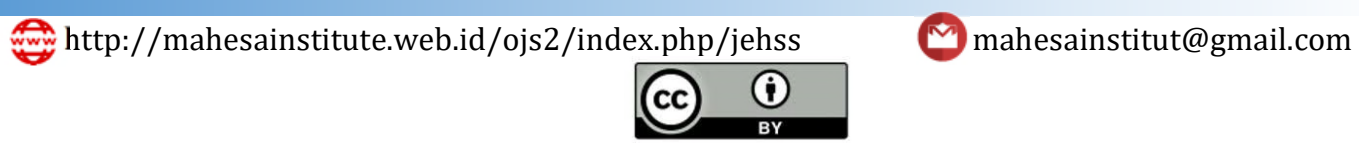


Tantangan Dalam Pemasukan Benih Dari Luar Negeri Ke Dalam wilayah Sumatera Utara.

Berdasarkan hasil wawancara yang dilakukan dengan pegawai Balai Karantina Pertanian Kelas II Medan tantangan dalam pemasukan benih impor adalah adanya penyakit organisme pengganggu tumbuhan yang ikut terbawa oleh media tumbuhan yaitu benih ke dalam wilayah Sumatera Utara. Pemerintah yang merupakan salah satu perwujudan dari negara harus mampu melaksanakan perlindungan (pencegahan) sebagaimana tertuang dalam tujuan negara Indonesia yaitu di alinea keempat pembukaan UUD Negara Republik Indonesia Tahun 1945, yaitu "melindungi segenap bangsa Indonesia dan seluruh tumpah darah Indonesia dan untuk memajukan kesejahteraan umum, mencerdaskan kehidupan bangsa, dan ikut melaksanakan ketertiban dunia yang berdasarkan kemerdekaan, perdamaian abadi dan keadilan sosial"

Sebagai implementasi dari alinea ke 4 pembukaan UUD Tahun 1945 pemerintah melalui UU (Undang - Undang) No. 21 Tahun 2019 Tentang Karantina Hewan, Ikan, dan Tumbuhan melakukan perlindungan dengan menyelenggarakan karantina bagi media pembawa (hewan, produk hewan,ikan, produk ikan, tumbuhan, produk tumbuhan, pangan,Pakan, PRG, SDG, Agensia Hayati, Jenis Asing Invasif, Tumbuhan dan Satwa Liar, Tumbuhan dan Satwa Langka,dan/atau Media Pembawa lain yang dapat membawa HpHK,HPIK, atau OPTK) sebagai upaya pencegahan masuknya organisme pengganggu tumbuhan yang bisa membahayakan kelestarian sumber daya alam (hewan, ikan, dan tumbuhan) juga dapat membahayakan bagi kehidupan manusia maupun lingkungan hidup. Yang dimana tidak menutup kemungkinan terjadi penurunan produktivitas bagi kelestarian sumber daya alam dan dapat mengancam kehidupan manusia, baik secara langsung (penyakit) maupun tidak langsung.

\section{SIMPULAN}

Pemasukan benih diatur khusus dalam UU No. 21 Tahun 2019 Tentang Karantina Hewan, Ikan dan Tumbuhan. PP No.82 Tahun 2000, Peraturan Menteri Pertanian No. 15 Tahun 2017 tentang Pemasukan Dan Pengeluaran Benih Hortikultura dan Peraturan Menteri Pertanian No. 127 Tahun 2014 tentang Pemasukan dan Pengeluaran Benih Tanaman. Pemasukan benih ke dalam wilayah Negara Indonesia khususnya wilayah Sumatera Utara diwajibkan memenuhi persyaratan administrasi dan persyaratan teknis yang dimana harus disertai dengan izin yang diberikan oleh Menteri Pertanian, kemudian membawa sertifikat kesehatan tumbuhan yaitu Phytosanitary Certificate (Pc) dari negara asal yang menyatakan bahwa media pembawa (benih) bebas dari penyakit atau organisme pengganggu tumbuhan yaitu HpHK,HPIK, atau OPTK.

Petugas Teknis perizinan pemasukan benih tidak mengalami kendala teknis hal ini ditandai dengan minimnya kasus yang terjadi. Benih yang mengandung penyakit organisme pengganggu tumbuhan pada media tumbuhan diwilayah Sumatera Utara dapat diatasi Petugas dengan melakukan pengawasan secara intensif pada tempat pemasukan dan melakukan karantina serta pengecekan secara berkala sebagai upaya perlindungan pencegahan yang dapat membahayakan kelestarian sumber daya alam (hewan dan tumbuhan), serta dapat membahayakan kehidupan manusia maupun lingkungan hidup.

\section{DAFTAR PUSTAKA}

Badan Karantina Pertanian. Impor Tumbuhan dan Produk Tumbuhan. Diunduh di https://karantina.pertanian.go.id/page-14-impor-tumbuhan-dan-produk tumbuhan.html. tanggal 27 Juni 2019.

BHP UMY. Penggunaan Benih Bermutu, Penting Bagi Peningkatan Produksi Pertanian. Universitas Muhammadiyah Yogyakarta,. Diunduh di https://www.umy.ac.id/penggunaan-benih-bermutupenting-bagipeningkatan-produksi-pertanian.html. tanggal 27 Juni 2019.

Diantha, I.M.P. (2017). Metodologi Penelitian Hukum Normatif Dalam Justifikasi Teori Hukum. Cetakan Kedua. Jakarta: Prenada Media Group.

Direktorat Jendral Bea dan Cukai. (2019). Bea Cukai Gagalkan Penyelundupan Tanaman Lewat Teluk Nibung. Diunduh di https://republika.co.id/berita/py9mhk368/bea-cukai-gagalkanpenyelundupan-tanaman-lewat-teluk-nibung tanggal 15 November 2019.

Diunduh di http://www.dpr.go.id/doksileg/proses1/RJ1-20160314-040925-2989.pdf. tanggal 17 Desember 2019.

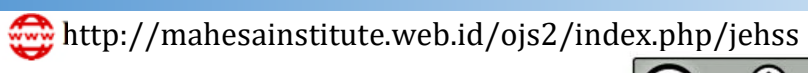


Efendi, J. \& Johny. (2018). Metode Penelitian Hukum Normatif Dan Empiris. Cetakan Kedua. Depok: Prenada.

Halim, M.R.A.A. (2017). Pelaksanaan Pemberian Izin Klinik Hemodialisa Di Kota Bandar Lampung. Jurnal Ilmiah Hukum Administrasi Negara. 4(2):1-14.

INDONESIA.GO.ID Portal Informasi Indonesia. Angka Pengenal Impor (API). Diunduh di https://www.indonesia.go.id/layanan/kepabeanan/ekonomi/angkapengenal-impor-api. tanggal 15 November 2019.

Litbang Pertanian. Petunjuk Teknis Tatacara Permohonan Izin Pemasukan Dan Pengeluaran Benih/Bibit/ Mikrobia Dari Dan Ke Luar Negeri Untuk Penelitian Diunduh di .http://www.litbang.pertanian.go.id/regulasi/4/file/Juknis_ekspor_impor_benih.pdf. tanggal 2 Februari 2019.

Muhammad, A. (2004). Hukum dan Penelitian Hukum. Bandung: Citra Aditya Bakti.

Muladi \& Dwidja, P. (2010). Pertanggungjawaban Pidana Korporasi. Jakarta: Kencana Media Group.

Qamar, N. Dkk. (2017). Metode Penelitian Hukum (Legal Research Methods). Makssar: CV. Social Politic Genius (SIGn).

Repository Universitas Maritim Amni (Unimar Amni) Semarang. Pelayanan Jasa Impor Barang Dikawasan Perdagangan Bebas Free Trade Zone Pulau Batam Oleh PT. Batam Indonesia Indah. Diunduh di http://repository.unimar-amni.ac.id/733/. tanggal 8 Januari 2020.

Rozi, et al. (2014). Strategi Formulatif Menuju Sistem Perbenihan Ideal Kedelai Di Sulawesi Selatan. Prosiding Seminar Hasil Penelitian Tanaman Aneka Kacang dan Umbi 2014. 5 Juni 2014.

Saraswati, R. (2013). Problematika Hukum Undang-Undang No.12 Tahun 2011 Tentang Pembentukan Peraturan Perundang-Undangan. Yustisia. 2(3): 97-103.

Soekanto, S. (2006). Penelitian Hukum Normatif. Jakarta: PT. Raja Grafindo Persada.

Sudjindro. (2009). Permasalahan dalam Implementasi Sistem Perbenihan. Buletin Tanaman Tembakau, Serat \& Minyak Industri. 1(2):92-100.

Yusuf, A.M. (2017). Metode Penelitian Kuantitatif, Kualitatif, Dan Penelitian Gabungan. Cetakan Keempat. Jakarta: Kencana.

UU (Undang - Undang) No. 21 Tahun 2019 Tentang Karantina Hewan, Ikan, dan Tumbuhan

UU (Undang - Undang) No 22 Tahun 2019 tentang Sistem Budi Daya Pertanian

Peraturan Pemerintah No. 14 Tahun 2002 Tentang Karantina Tumbuhan.

Permentan No. 127 Tahun 2014 tentang Pemasukan dan Pengeluaran Benih Tanaman.

Permentan No. 15 Tahun 2017 tentang Pemasukan Dan Pengeluaran Benih Hortikultura. 